\title{
Novel approach for issues identification in transboundary water management using fuzzy c-means clustering
}

\author{
Subash Prasad Rai ${ }^{1,2} \cdot$ Nayan Sharma ${ }^{1,2} \cdot$ Anil Kumar Lohani $^{3}$
}

Received: 5 September 2016 / Accepted: 27 December 2018 / Published online: 2 January 2019

(c) The Author(s) 2019

\begin{abstract}
Rivers, a major freshwater resource, are transboundary in nature (310 international basins) and are not governed by any water agreements. Scientific knowledge based on transboundary water resources is confined; hence, the identification of "knowledge gaps" to smoothen decision making in water management is necessary. To figure out the issues that affect water sharing is deemed important. This paper highlights the core issues involved in transboundary water management and prioritizes the identified issues using fuzzy c-means clustering algorithm. A group of 30 experts from various fields were consulted to rank the issues which were clustered to determine the prioritized rank. In a hypothetical basin affected by all the transboundary issues, flood control and benefit sharing are rated with very high importance. Prioritization would help in the identification of issues of high relevance that affect water sharing. This may facilitate efficient water sharing agreements among riparians and be useful in international water governance.
\end{abstract}

Keywords Transboundary water resources $\cdot$ Water management $\cdot$ Fuzzy c-means clustering $\cdot$ Cluster center $\cdot$ Prioritization . Riparians

\section{Introduction}

Unlike international disputes over other natural resources such as oil, there is no viable alternative to water. Without requisite quantity or quality of water, economic development as well as agricultural production would grind to a halt. This would lead to greater human suffering and threaten societal stability. Humanity's primary sources of water are freshwater rivers. Most of the freshwater rivers are transboundary in nature, i.e., they cross at least one political border, either a border within a nation or an international boundary. According to the Transboundary Freshwater Dispute Database (TFDD), the world has 276 international river basins (TFDD 2012) updated to 310 international river basins in 2017 (https://transboundarywaters.science.oregonstate.edu/conte nt/data-and-datasets). More than $45 \%$ of the land surface on

Subash Prasad Rai

subashbitsindri@gmail.com

Floodkon Consultants LLP, Roorkee, India

2 Department of Water Resources Development and Management, IIT Roorkee, Roorkee, India

3 National Institute of Hydrology Roorkee, Roorkee, India the Earth is covered by transboundary international river basins (Loucks and van Beek 2005). As the transboundary waters flow through various sovereign nations, they create social, economic, and hydrological interdependencies. Though international rivers can be a potential source of conflict, they still create possibilities as well as opportunities for cooperation. Successful transboundary water management promotes economic growth alongside regional peace and security which can thwart the much-anticipated water wars (Rai et al. 2017a, b).

In the absence of cooperation over the shared resources, each state must use the water in the river to its best advantage before it crosses international borders and becomes unreachable. Because of this, transboundary rivers can be potential loci for conflict over the use of the shared river. Scientific knowledge based on transboundary water management is more often fragmented which mostly considers specific cases and more particularly deals with specific key issues rather than covering a range of issues. Transboundary water management lacks inter-issue coordination and cross-sectoral management. This is easily visible in any international water treaties which generally discuss only a few issues from a range of issues. For example, the Indus water treaty deals with water quantity, the Danube River 
Agreement deals with water quality, and the Columbia River Agreement deals with flood control and hydropower. Hence, there is a growing need to take a holistic view of the range of issues involved in transboundary water management (Rai et al. 2016). This may supplement policy makers with more polished and informed decision-making opportunities in international water management.

The major thrust of the paper is on the prioritization of issues using FCM clustering and the idea is to propagate the use of fuzzy methodology in transboundary water management. Fuzzy logic approach has been used by numerous scholars in the fields not limited to medical diagnosis, data mining, information technology, robotics, water quality assessment, hydrology, reservoir operation, flood forecasting, water resource allocation, and risk assessment (Di Lascio et al. 2002; Kucukmehmetoglu et al. 2010; Lee 1996; Lohani et al. 2006, 2012; Lu and Lo 2002; Lu et al. 1999; Mitra et al. 2002; Rai et al. 2014, 2017c; Sadiq et al. 2004; Saffiotti 1997). Fuzzy approach finds greater appeal among all sections including engineers, regulators, decision makers, policy makers, managers, expert panels, and other stakeholders. Politics is a major component of water management in transboundary rivers. The hydropolitics surrounding international rivers significantly affects the outcomes of negotiation and decision making by riparians in situations of conflict and cooperation. The political decision-making process involves linguistic data, which are vague and imprecise, and hence, a fuzzy inference system (FIS) finds its utility in transboundary water management. FIS introduces a soft dimension due to the inclusion of qualitative (linguistic) data.

Water resources management decisions are not an outcome of measured data only, because politics provide a dynamic process, which can easily change over time and cannot be measured crisply but involves immeasurable uncertain and fuzzy aspects. Fuzzy logic (FL) algorithm is also a powerful technique for modeling the nonlinear, uncertain, and complex systems with numerical and linguistic data in the form of an expert system (Özger and Şen 2007; Şen 2004, 2009; Simonovic 2012). By providing a systematic framework for computing with fuzzy logic greatly amplifies the power of human reasoning (Zadeh 1968).

This paper throws light on the range issues discussed in transboundary water management for international rivers. The issues considered here are in coherence with the list of issues discussed in the Basins At Risk (BAR) analysis carried out at Oregon State University. The highlight of this paper is the prioritization of the issues involved in transboundary river water sharing using FCM clustering algorithm. The FCM methodology is an up gradation over the hard clustering technique. Hard clustering partitions data into discrete clusters where each data element belongs exactly to one cluster. The objective of prioritization of issues in the present study is carried out by a novel approach FCM clustering. The data elements of fuzzy clusters can have different membership grades corresponding to different clusters (Jones 2012). The paper is divided into two sections: The first deals with how the issues which affect transboundary water sharing have been derived from the literature, while the other prioritizes the identified issues. The issues derived from the literature are cross-checked with the study carried out at Oregon State University under the BAR analysis of water events across the world. This has been carried out to check the relevance of the transboundary issues addressed here. The prioritization of issues would help in the identification of issues of high relevance which can facilitate smooth and efficient water compacts between riparians.

\section{Water conflict and conflicting issues}

A river is a naturally gifted treasure. It is essential to figure out the issues that affect the river for successful river management (Tiwari and Sharma 2014). The laws of nature and humans both prescribe that the ambient water resource must be shared by its dependents (Dellapenna 2007). The study conducted at the University of Alabama which studied 145 treaties dating from as early as 1870 which deal with water per se, and excluding those which deal only with boundaries, navigation, or fishing rights revealed interesting trends about international water treaties.

Most treaties focus on hydropower and water supplies: Fifty-seven (39\%) treaties discuss hydroelectric generation, nine (6\%) mention industrial uses, six (4\%) mention navigation, six (4\%) primarily discuss pollution, while thirteen (9\%) focus on flood control. Seventy-eight (54\%) treaties have monitoring provisions (which includes data sharing, surveying, and schedules for collecting data). Fifty-four (37\%) have clearly defined allocations (Hamner and Wolf 1998). International water agreements or treaties still do not govern more than one third of the 263 international catchments with only some 30 having truly cooperative institutional agreements (Draper 2002, 2006, 2012b). Allocation of the scarce water resource to meet the various demands is considered the core issue in water management (Draper 2012b). Here the authors bring out the issues which hold relevance when transboundary water sharing is discussed between riparians.

Various scholars (Association 2004; Bakker 2007, 2009; Dellapenna 2007; Draper 1997, 2007; Gerlak et al. 2011; Hamner and Wolf 1998; Lowi 1995; Pahl-Wostl et al. 2008; Phelps 2007; Qaddumi 2008; Wolf 1997, 1998, 1999a; Zeitoun and Warner 2006) have discussed and reported the different parameters which influence water sharing in some form or the other. For water conflict resolution, one needs to have knowledge of all the issues that are responsible for it. There is no complete literature available regarding the 
issues which impact transboundary water sharing. The available literature has discussed the issues at times but in bits very often ignoring factors with little significance or external factors.

Here the issues include the direct as well as indirect aspects related to transboundary water interactions. The direct ones are those which are in direct connection to the water or its management, while the indirect ones are those which deal with external factors affecting transboundary water interaction, the negotiation process, and lastly the decision-making process. This is to include the more recent advances in transboundary management which advocates shifting away from sharing the physical water and move toward a more comprehensive view of benefits and its sharing (Rai and Sharma 2016). To formulate the list of relevant transboundary issues, the available literature was searched with the certain keywords concerning international water resources sharing.

The search database included keywords: irrigation, lake, river, canal, pollution, dam, hydro, water, barrage, reservoir, river, navigation, water resources, hydropower, hydroelectricity, stream, tributary, diversion, water quality, flood, drought, channel, relations, development, dispute, conflict, war, accord, negotiation, treaty, cooperation, hostility, treaty, agree, negotiate, resolution, commission, secretariat, joint management, basin management, peace, accord or "peace accord," settle, collaboration, disagree, sanction, water quantity, water sharing, data, or "data sharing," data exchange, flow, hydrohegemony, hydropolitics, environmental flow, ecology, EFR, cost, benefit-cost, water economics, benefit, sharing, or "benefit sharing," religion, culture, social, hydraulic, infrastructure, or "hydraulic infrastructure," riparian, bilateral, multilateral, international water law, water convention, water sharing principles, convention on the law of the non-navigational uses, Helsinki rules, water law, water policy, fishing, water boundary, river island, river boundary.

The search database helped in formulating the list of issues. These keywords have been used more often in the literature contributing to transboundary water management. Table 1 shows the supporting literature from which the corresponding issue has been derived out which affects transboundary water sharing. The literature cited in the table is not absolute, but they are just an indication that the issue has been discussed and debated around the world. There are many more studies which could be cited, and only a few have been cited here to support the basis of selection of the issue. It should not be considered that the cited literature is absolute.

In the Basins at Risk (BAR) analysis carried out at the Oregon State University, a list of issues was formulated to study the water events across the world. The list formulated in the present study is a step forward and superior keeping in view of the latest developments. It includes the issues highlighted in the BAR analysis and also adds a few external issues. The ones which are in accordance with BAR analysis are: water quantity, water quality, navigation, flood control, hydraulic infrastructure (includes irrigation, hydropower and infrastructure/development issues of BAR), conflicting internal law and policies (incorporates fishing, border issues, territorial issues of BAR), benefit sharing (includes economic development, joint management, technical cooperation/assistance of BAR). The additional issues are data sharing, hydrohegemony, environment flow and ecology, cost economics, religious, cultural and social issues, number of riparians involved, no ratified international law.

The issues of cost economics and benefit sharing though seem very similar as both deal with monetary aspects but are fundamentally different. Cost economics deals with how to arrange for funds for any water management or infrastructure project. Many nations are incapable of bearing the financial burden of water resource projects. It may happen in many basins which are governed by underdeveloped and developing countries and may not be affected by physical water scarcity, but they may certainly be gripped by economic water scarcity. This means that these basins lack the financial resources to use water at its merits. In such cases, these countries need to arrange for funding from international agencies like the World Bank or the Asian Development Bank. While benefit sharing deals with the economics of the projects after they have been completed and are ready to yields benefits, then the issue of benefit sharing comes into picture. Thus, it is clear that how cost economics is different from benefit sharing as far as water resources are considered. An example of cost economics is the Indus Water Treaty where the World Bank along with the government of Australia, Canada, West Germany, New Zealand, the USA, and the UK contributed largely in developing the water resources in India and Pakistan.

Resolution of water conflicts is all the more difficult with the nonexistence of single set of water law and policy or adequate legal conflict resolution forum. Information and data sharing engender good will and enhance confidence building among riparian states. Another important concern is that most of the international basins are multilateral, but most of the treaties are bilateral. With the effect of climate change being more pronounced, extremes of temperatures and rainfall can be experienced more often. This may lead to devastating floods which knows no political boundaries. Not just in the basins not governed by any treaty, but an in-depth analysis of the present water treaties will certainly reflect all the above issues in some way or the other either intrinsically or extrinsically. Table 1 shows the international basins affected by the various issues. 
Table 1 Issues affecting international basins supported by the literature

\begin{tabular}{|c|c|c|}
\hline Issue & Supporting literature & Affected basin \\
\hline Water quantity and flow timings & $\begin{array}{l}\text { Dellapenna (2007), Draper (2012b), Eheart } \\
\text { (2002), Phelps (2007) }\end{array}$ & $\begin{array}{l}\text { All international basins [Ex. GBM Basin (Indo- } \\
\text { Bangladesh)] }\end{array}$ \\
\hline Data sharing & $\begin{array}{l}\text { Draper (2007), Gleditsch et al. (2006), Sned- } \\
\text { don and Fox (2006), Toset et al. (2000), Wolf } \\
(1999 \text { c) }\end{array}$ & $\begin{array}{l}\text { All international basins [Ex. Brahmaputra Basin } \\
\text { (China-India)] }\end{array}$ \\
\hline Water quality & $\begin{array}{l}\text { (Bennett (2000), Boos-Hersberger (1997), Jacobs } \\
\text { (2002), Shmueli (1999), Sigman (2001) }\end{array}$ & $\begin{array}{l}\text { All well-developed international basins [Ex. Dan- } \\
\text { ube Basin, Ganges Basin (Indo-Bangladesh)] }\end{array}$ \\
\hline Hydro hegemony and political influence & $\begin{array}{l}\text { Warner (2004), Warner and Zeitoun (2008), } \\
\text { Waterbury (2002), Zeitoun et al. (2010), Zei- } \\
\text { toun and Warner (2006) }\end{array}$ & $\begin{array}{l}\text { All international basins [Ex. Mekong Basin (Thai- } \\
\text { land-Cambodia-Laos-Vietnam)] }\end{array}$ \\
\hline Environment flow and Ecology & $\begin{array}{l}\text { Burchi (2012), Davis (2007), Jacobs (2002), Kal- } \\
\text { lioras et al. (2006), Kistin and Ashton (2008), } \\
\text { Richter (2010) }\end{array}$ & All international basins (Ex. Danube Basin) \\
\hline Cost economics & $\begin{array}{l}\text { Davis (2007), Lee and Floris (2003), Winpenny } \\
\text { and Camdessus (2003) }\end{array}$ & $\begin{array}{l}\text { All international basins which involves underde- } \\
\text { veloped and developing nations [Ex. Indus Basin } \\
\text { (Indo-Pak)] }\end{array}$ \\
\hline Benefit sharing & $\begin{array}{l}\text { (Dombrowsky (2009), Nicol et al. (2001), } \\
\text { Phillips et al. (2006), Sadoff and Grey (2002, } \\
\text { 2005), Turton (2008) }\end{array}$ & $\begin{array}{l}\text { All international basins [Ex. Columbia Basin (the } \\
\text { USA-Canada)] }\end{array}$ \\
\hline Religious, cultural and social issues & $\begin{array}{l}\text { van Binsbergen (2003), Gleick (2003), Pahl- } \\
\text { Wostl et al. (2008), Reuss (2002) }\end{array}$ & $\begin{array}{l}\text { All international basins [Ex. Ganges Basin (Indo- } \\
\text { Nepal)] }\end{array}$ \\
\hline Hydraulic infrastructure & $\begin{array}{l}\text { Dams (2000), Grey and Sadoff }(2006,2007) \text {, } \\
\text { Zeitoun and Warner (2006) }\end{array}$ & $\begin{array}{l}\text { International basins involving developing nations } \\
\text { [Ex. Brahmaputra Basin (Indo-China)] }\end{array}$ \\
\hline Navigation & Bernauer (1997), Wolf (1999b, 2001) & $\begin{array}{l}\text { Few international basins mainly in Europe (Ex. } \\
\text { Danube Basin) }\end{array}$ \\
\hline Flood control & $\begin{array}{l}\text { Bakker (2007, 2009), Rahaman and Varis (2005), } \\
\text { Wolf (1998) }\end{array}$ & $\begin{array}{l}\text { Large number of international basins (Ex. GBM } \\
\text { Basin) }\end{array}$ \\
\hline Number of riparians involved & $\begin{array}{l}\text { (Hamner and Wolf 1998, Ma et al. 2007, Wolf } \\
\text { 1999b) }\end{array}$ & $\begin{array}{l}\text { All multilaterally shared river basins (Ex. Mekong } \\
\text { Basin, Nile Basin) }\end{array}$ \\
\hline No ratified international law & $\begin{array}{l}\text { Dellapenna (1996), Dinar et al. (2007), Draper } \\
\text { (2012a), Fischhendler (2004), Frey (1993), } \\
\text { Wolf (1998, 2002) }\end{array}$ & $\begin{array}{l}\text { All international basins [Ex. Brahmaputra Basin } \\
\text { (China-India)] }\end{array}$ \\
\hline Conflicting internal law and policies & $\begin{array}{l}\text { Cummings et al. (2002), Dellapenna (2001), } \\
\text { Draper (2004, 2012a), Grant (2003), Sanchez } \\
\text { (1997), Şen (2013) }\end{array}$ & $\begin{array}{l}\text { All international basins [Ex. Ganges Basin (Nepal- } \\
\text { India)] }\end{array}$ \\
\hline
\end{tabular}

\section{Prioritization of transboundary river water sharing issues}

After the identification of the issues that affect transboundary water sharing through rigorous literature review, a study was undertaken to prioritize the issues according to their importance. Though each river basin is different from the others, the relative importance of the issues will help the riparians to resolve the issues in a scientific manner. A hypothetical river basin is considered which is assumed to be affected by all the 14 number of issues identified through studies. To prioritize the issues, a group of 30 experts was consulted. The experts include representatives from government officials, water resources engineers and practitioners, NGO's, journalists, economists, environmentalists, water users, and researchers. An attempt has been made to maintain a balance between the numbers of experts from various fields.
Experts from all major and allied fields were consulted from the Indian region. Government officials and representatives include both central and state government employees. Water resources engineers include the on-field experts who directly have to deal with complex situations. Experts from NGO's included the very specific NOG's working in water resources conservation and management. Economists are the experts in the area of economics who have the best idea of cost-benefit, finances, etc. The environmentalists include experts working in the areas of environment conservation, ecology, marine life, aquaculture, etc. Researchers which also include academicians are the ones working extensively as well as intensively in water resources. They introduce new technologies, theories, frameworks, or approaches in the management process. Lawyers are the ones who deal with any legal issues that arise in the due course of negotiation, document preparation, drafting rules and guidelines, 
etc. Lastly, the water users are the end users of the water. A good blend of experts has been selected for this study to get proper results. The bifurcation of the number of experts from various disciplines is given in Table 2.

The experts were selected according to the knowledge and experience in their respective fields. The experts selected have sufficient working knowledge of water management. Some of the experts have working extensively in transboundary water management. The government representatives and officials consulted are involved in policy and decision making. All the experts consulted are from India. The experts gave their views under the clause of anonymity so the particular details of the experts have not been disclosed. The authors contacted them in person to discuss the issues in detail and take their views after thorough deliberation. The experts were to rank the issues according to the relative importance. The following questionnaire was given to the experts:

Questionnaire: Consider a hypothetical river basin that is transboundary in nature and is gripped with all the direct and indirect issues discussed above.

1. Prioritize the issues in the order of importance keeping in view the hypothetical river basin.

The order of priority should consider the following aspects:

- Which of the issues is more relevant with respect to joint management of water resources?

- Which of the issues cause hindrance or is used as a tool to stall the negotiation process in the path of transboundary water management?

- While negotiating among riparians which of the identified issues should be discussed first that would help better manage the basin as a whole.

The ranks provided by the experts corresponding to the transboundary river sharing issues are given in Table 3.

Table 2 Details of the consulted experts

\begin{tabular}{ll}
\hline Fields of expert & $\begin{array}{l}\text { Number } \\
\text { (count) }\end{array}$ \\
\hline Government representatives and officials & 4 \\
Water resources engineers and experts & 4 \\
NGO's & 4 \\
Economists & 4 \\
Environmentalists & 4 \\
Researchers & 4 \\
Lawyers & 4 \\
Water users & 2 \\
\hline
\end{tabular}

After assembling the ranks, it was analyzed with FCM clustering algorithm to find out the priority order (rank) of the issues affecting transboundary rivers. FCM clustering methodology has been adopted.

\section{Prioritization methodology: fuzzy c-means (FCM) clustering}

Prioritization is to arrange, organize, or deal with in order of importance. As a principle, it means doing "first things first"; as a process, it means evaluating a group of items and ranking them in their order of importance or urgency. It is particularly important when management of transboundary water resources is involved with water wars in the horizon. When conflict management is involved, prioritization of issues is considered of high relevance. This helps to bring to focus the core issues which need to be addressed immediately in order to manage conflicting claims to the common resources.

A cluster is a set of elements which have similarities between them and dissimilarities with objects belonging to other clusters. Depending on the characteristics of the data and the intended purpose for clustering, different measures of similarity may be used to classify the data into various clusters. The similarity measure controls the manner in which clusters are fashioned. Here, in the present study, FCM clustering has been used for clustering the ranks given by experts. FCM methodology clusters the ranks of each parameter and gives the cluster center which represents the prioritized rank of the issue.

Fuzzy clustering is a class of algorithms used for the analysis of clusters (popularly known as FCM clustering) in which the allocation of data elements to clusters is not hard but fuzzy in the same sense as fuzzy logic (Rezankova and Husek 2012). Fuzzy cluster analysis is employed to partition a given set of data or objects into clusters which can be groups, subsets, and classes. In fuzzy clustering, the allocation of data elements to clusters is not "hard" but "fuzzy" which is referred to as soft clustering (Belli et al. 2007). This is due to the property of fuzzy clustering which allows data objects to belong to more than one cluster (soft). Each element is associated with the clusters with a set of membership levels (Shankar et al. 2013). The process is to assign membership degrees and then using the assigned memberships to reassign data objects to one or more clusters. The strength of the association between that data object and a particular cluster is represented by the membership levels. The partition should follow homogeneity within clusters and heterogeneity between clusters.

Fuzzy c-means clustering has been preferred over simple averaging of the ranks obtained from the experts. This is because FCM accommodates the fuzziness in the data

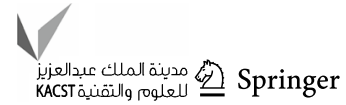




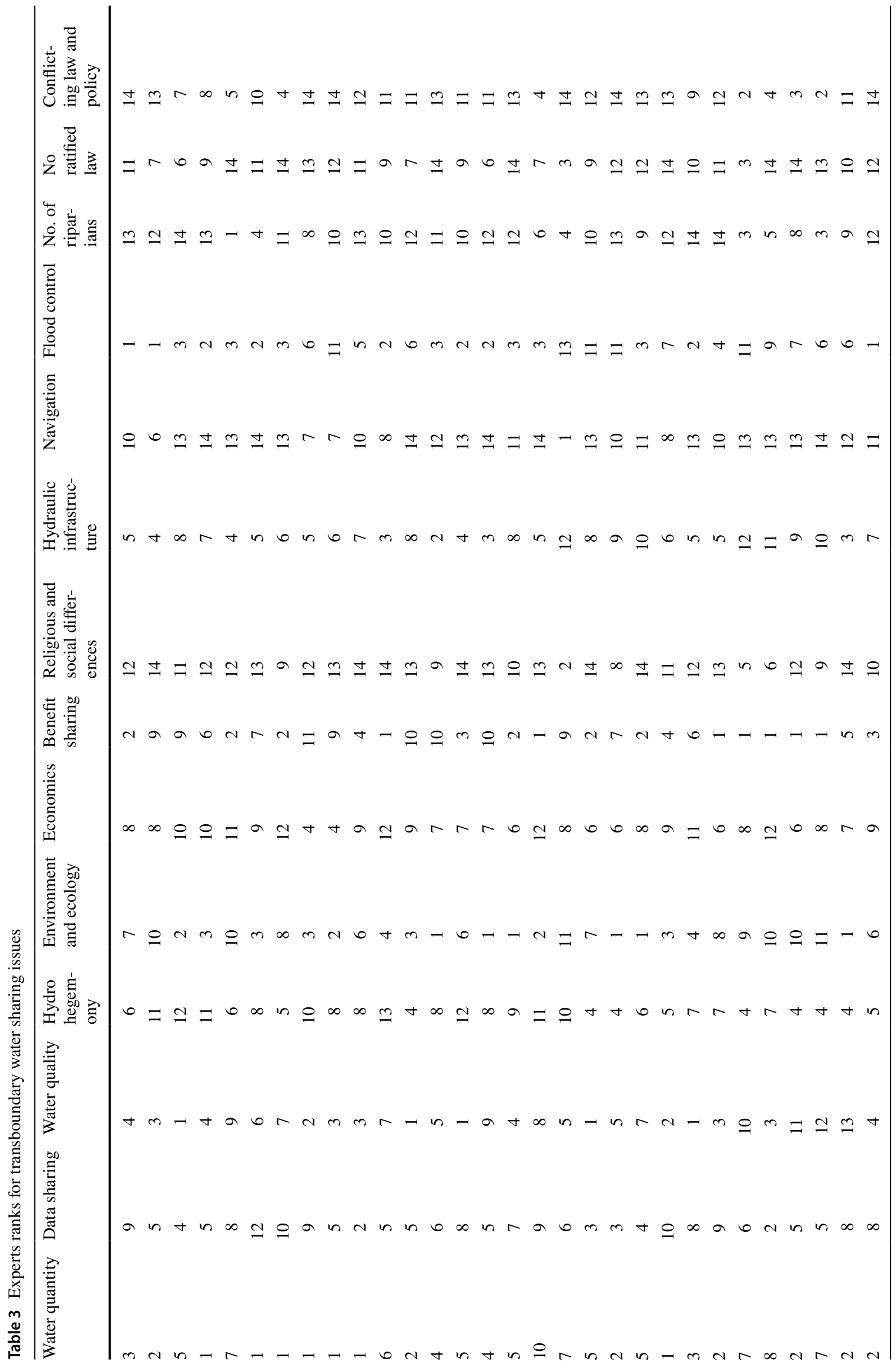


collected from the experts. Moreover, simple averaging can result in same prioritized rank for more than one issue which can be avoided using FCM which does fulfill the objective of prioritization of the issues which affect or influence transboundary water sharing. Since all the experts have different backgrounds, they all view the same problem in a different way. So simple averaging cannot be the procedure that can be employed in case of prioritization of issues as it cannot deal with the fuzziness caused due to the variety in experts. As the main objective is prioritization of the issues, the theory and mathematics of FCM have not been dealt in detail. The utility of FCM has been used in prioritizing in the present study.

\section{Analysis}

In the present study, fuzzy cluster analysis, i.e., the FCM algorithm, is not used to cluster the individual ranks of each parameter into groups, rather the intended purpose is to find the center of the cluster consisting of individual ranks provided by the experts for each of the parameters. This means that the data (ranks) are beforehand classified into groups in the form of ranks awarded to the each of the issues. Hence, a total of 14 clusters were formed for the corresponding 14 issues. Each column in Table 3 represents a cluster. The objective is to find the center of all the 14 clusters. For the intended purpose, the "findcluster" tool given in MATLAB is used.
MATLAB is the Language of Technical Computing. In 2004, MATLAB had around one million users across industry and academia. MATLAB users come from various backgrounds of engineering, science, and economics to analyze and design the systems and products transforming our world. MATLAB (matrix laboratory) is a multi-paradigm numerical computing environment and fourth-generation programming language. A proprietary programming language developed by MathWorks, MATLAB allows matrix manipulations, plotting of functions and data, implementation of algorithms, creation of user interfaces, and interfacing with programs written in other languages, including $\mathrm{C}$, $\mathrm{C}++$, Java, Fortran, and Python. It is used for machine learning, signal processing, image processing, computer vision, communications, computational finance, control design, robotics, and much more.

The clustering tool in MATLAB has two variations, namely subtractive and FCM, in the "findcluster" tool. In the present study, the clustering is done with FCM methodology rather than subtractive methodology. The basic layout of clustering tool with FCM algorithm is shown in Fig. 1.

\section{FCM clustering results}

Every cluster represents the corresponding issue which affects transboundary water sharing, and the cluster center represents the prioritized rank of the issue. The final result as obtained from FCM clustering algorithm is given in Table 4.

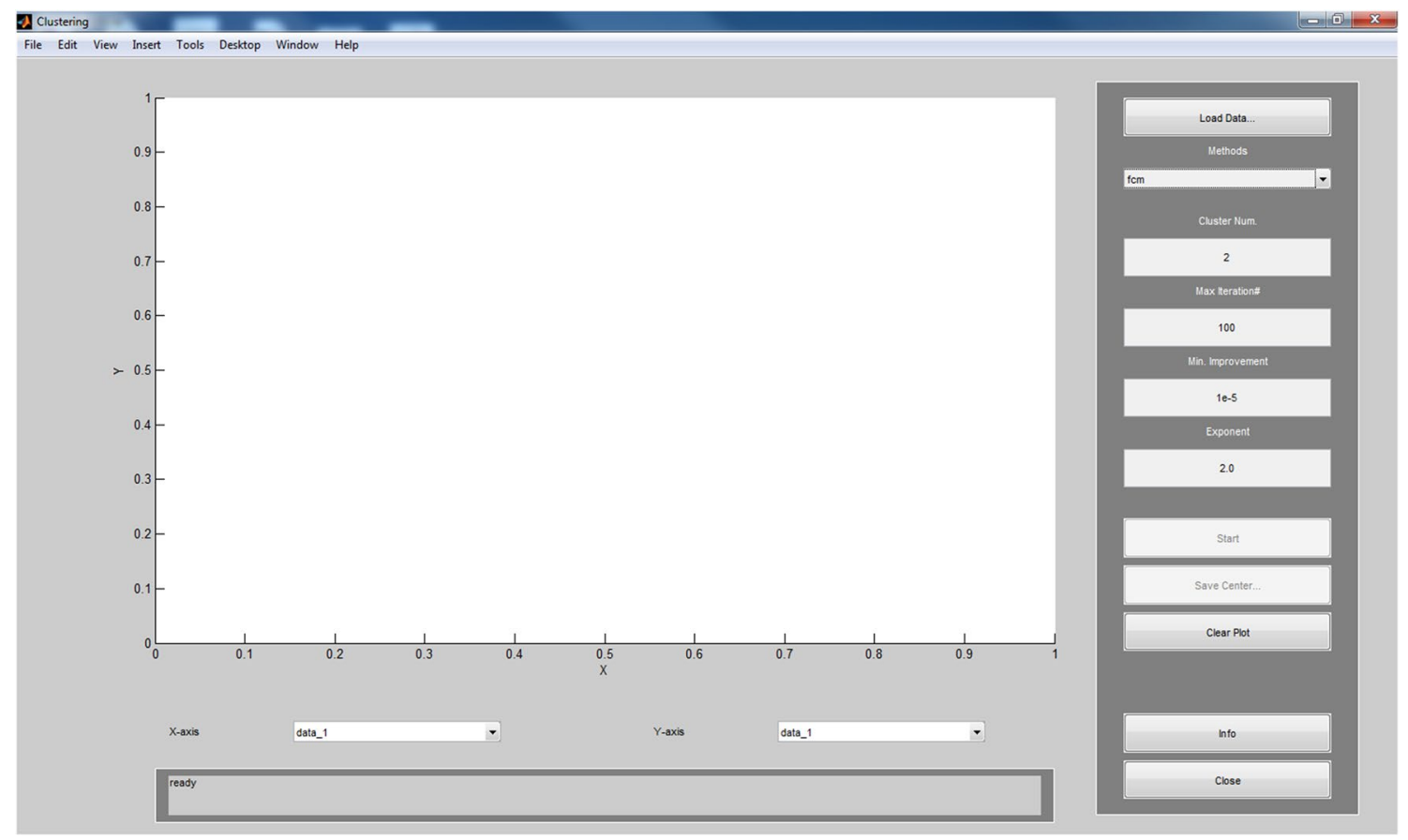

Fig. 1 Basic layout of clustering toolbox in MATLAB 
The issues in Table 4 have been placed according to their prioritized ranks as obtained by FCM clustering algorithm. The results as obtained by FCM clustering have been compared with that of the simple average. There is a marked difference in the ranks obtained from FCM and simple average. As simple average does not consider the fuzziness, the results obtained from FCM have been further used in the study. For more clarity, the graphical result as obtained from FCM clustering is shown in Fig. 2 which highlights the clustering with the cluster center for the issue of water quantity and flow timings. Figure 2 depicts the typical clustering in two-dimensional feature space where $X$-axis and $Y$-axis

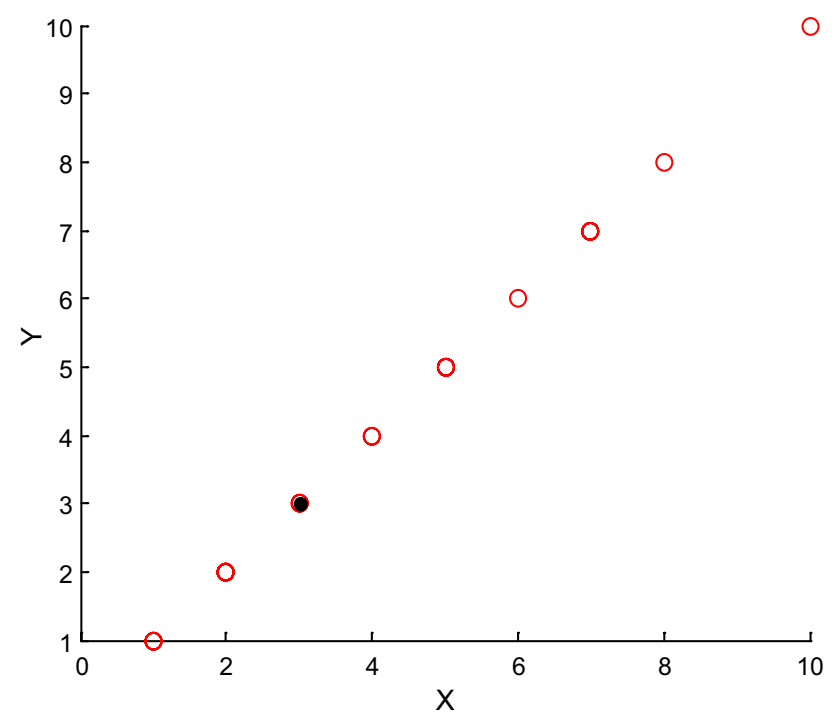

Fig. 2 Cluster of water quantity and flow timings parameter represent the pairwise comparison of ranks obtained from the experts with respect to transboundary issues.

The result derived from FCM clustering provides better insights to supplement transboundary water management. The issue of flood control has topped the table, and it rightly deserves the place. The result of the study conducted by Bakker (2007) which comprised of 1760 river floods that occurred during the period of 1985-2005, i.e., 21 years, reveals startling facts. These floods caused 112,000 casualties, affected around $354,370,000$ people, and resulted in US\$6.87 $\times 10^{11}$ fiscal dent. During this period, only 175 (only about one tenth) out of the total 1760 river flood events were transboundary, but they caused around 37,000 casualties, affected about $210 \times 10^{6}$ people, and resulted in more than US\$97 $\times 10^{9}$ fiscal dent which constitute a significant number, greater than $10 \%$ in terms of the total number of deaths, affected people, and fiscal dent caused by the total number of river floods (Bakker 2007). The world needs to come together to reduce the effect of transboundary floods as it is devastating in every term be it causalities, people affected or economically.

Then, next is benefit sharing as the second priority. Until and unless there is equitable sharing of benefits, most countries defer joining any kind of treaty. The reason for it is that water is now no more a social asset only, and it is now considered as a socioeconomic asset. Water adds to the economic resources of the nations. Economic benefits are the driving force behind the water sharing. In many cases, the benefits are loaded in favor of the more powerful. Equitable and just benefit sharing mechanisms need to be developed in the right spirit so that all nations come forward for joint cooperation. In the times to come, with the commercialization of water, benefit sharing will certainly provide the
Table 4 Prioritized rank of transboundary issues

\begin{tabular}{lcc}
\hline Issues & $\begin{array}{l}\text { Prioritized rank from } \\
\text { FCM }\end{array}$ & $\begin{array}{l}\text { Prioritized rank } \\
\text { from simple aver- } \\
\text { age }\end{array}$ \\
\hline Flood control & 1 & 3.7 \\
Benefit sharing & 2 & 6.4 \\
Water quantity and flow timings & 3 & 5.1 \\
Water quality & 4 & 7.4 \\
Hydraulic infrastructure & 5 & 5.1 \\
Hydro hegemony and political influence & 6 & 8.3 \\
Environment and ecology & 7 & 4.7 \\
Economics & 8 & 11.3 \\
Data sharing & 9 & 6.6 \\
Navigation & 10 & 11.2 \\
No ratified international law & 11 & 5.0 \\
Religious and cultural differences and social issues & 12 & 9.6 \\
Number of riparians involved & 13 & 10.4 \\
Conflicting internal law and policies of riparian & 14 & 9.9 \\
\hline
\end{tabular}

مدينة الملك عبدالعزيز

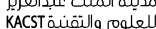


strong driving force that will bring together hostile riparians to work together.

Benefit sharing is followed by issues pertaining to water quantity which is further followed by water quality. Number of riparians involved and conflicting internal law and policies are issues of low priority. One very important feature which is revealed from the study is that the absence of ratified international law is not ranked high on priorities chart. This means that had there been ratified international law, the scenario might not have been very different from what it is right now. The issue of hegemony has been prioritized quite high. This reveals that there is growing realization about how the hegemony of the riparians influences the final outcome in water sharing process. Even till date navigation has not lost its shine completely and still finds relevance in numerous river systems.

\section{Conclusion}

1. Allocation of the water resources to meet the various demands which is considered to be the core issue (Draper 2012b) may not necessarily be the issues of prime importance in all river basins.

2. Though all river basins do not have similar characteristics, the prioritization algorithm suggested through this study using hypothetical river basin affected by all the issues can be used to study and analyze in detail the international river basins of the world.

3. The methodology as suggested by the authors in this paper can be used in transboundary water management in order to bring to fore the prime issues concerning particular basins.

4. At first, it is suggested to know the issues which affect particular basin; then, FCM clustering algorithm can be used as a methodological tool to carry out the preliminary analysis of shared basins.

5. The application of the FCM approach in management of international river basins is the highlight of the study. The approach may be useful in transboundary water management and understanding international water conflicts. This approach should help in more informed decision making by various governments, intergovernmental agencies, etc.

\footnotetext{
Acknowledgements The data used in the study were obtained from the experts consulted by the authors in person. The data have been attached as the data file separately in the submission. The literature was made available by the MGCL library of IIT Roorkee, and the data can be accessed through the link http://mgcl.iitr.ac.in/. I extend my gratitude toward the experts as well as IIT Roorkee library for providing the required data.
}

Authors' contributions Dr. Subash Prasad Rai made substantial contributions to conception and design, carried out the analysis, and drafted the manuscript. Prof. Nayan Sharma made substantial contributions to conception and design and helped in interpretation of results. Dr. Anil Kumar Lohani made substantial contributions to conception and design and was involved in drafting the manuscript.

\section{Compliance with ethical standards}

Conflict of interest The authors have read SpringerOpen's guidance on competing interests, and there is no competing interest on financial and non-financial matters.

Open Access This article is distributed under the terms of the Creative Commons Attribution 4.0 International License (http://creativeco mmons.org/licenses/by/4.0/), which permits unrestricted use, distribution, and reproduction in any medium, provided you give appropriate credit to the original author(s) and the source, provide a link to the Creative Commons license, and indicate if changes were made.

\section{References}

Association IL (2004) Berlin rules on water resources. Int Law Assoc, Berlin

Bakker MHN (2007) Transboundary river floods: vulnerability of continents, international river basins and countries. Oregon State University, Corvallis

Bakker MHN (2009) Transboundary river floods and institutional capacity JAWRA. J Am Water Resour Assoc 45:553-566

Belli F, Eminov M, Gökçe N (2007) Coverage-oriented, prioritized testing - a fuzzy clustering approach and case study. In: Bondavalli A, Brasileiro F, Rajsbaum S (eds) Dependable computing. LADC 2007. Lecture Notes in Computer Science, vol 4746. Springer, Berlin, Heidelberg, pp 95-110

Bennett LL (2000) The integration of water quality into transboundary allocation agreements Lessons from the southwestern United States. Agric Econ 24:113-125

Bernauer T (1997) Managing international rivers. In: Young OR (ed) Global governance: drawing insights from the environmental experience. The MIT Press, Cambridge, pp 155-196

Boos-Hersberger A (1997) Transboundary water pollution and state responsibility: the Sandoz Spill. Ann Surv Int Comp Law 4:103

Burchi S (2012) A comparative review of contemporary water resources legislation: trends, developments and an agenda for reform. Water Int 37:613-627

Cummings RG, Keeler A, Thompson B (2002) Georgia water-"A public resource or a comodity": what are the real policy questions?. University of Georgia, Georgia

Dams WCo (2000) Dams and development: a new framework for decision-making. World Commission on Dams, London

Davis MD (2007) Integrated water resource management and water sharing. J Water Resour Plan Manag 133:427-445

Dellapenna JW (1996) Two rivers and the lands between: mesopotamia and the international law of transboundary waters. BYU J Public Law 10:213

Dellapenna JW (2001) The importance of getting names right: The myth of markets for water. In: Phelps D, Shelke G (eds) Bridging the gap: meeting the world's water and environmental resources challenges. American Society of Civil Engineers, Reston, pp 1-19. https://doi.org/10.1061/40569(2001)339

Dellapenna JW (2007) Transboundary water sharing and the need for public management. J Water Resour Plan Manag 133:397-404

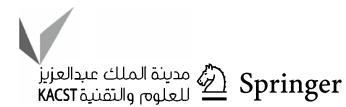


Di Lascio L, Gisolfi A, Albunia A, Galardi G, Meschi F (2002) A fuzzy-based methodology for the analysis of diabetic neuropathy. Fuzzy Sets Syst 129:203-228

Dinar A, Dinar S, McCaffrey S, McKinney D (2007) Bridges over water: understanding transboundary water conflict, negotiation and cooperation. World Scientific, River Edge

Dombrowsky I (2009) Revisiting the potential for benefit sharing in the management of trans-boundary rivers. Water Policy 11:125-140

Draper SE (1997) International duties and obligations for transboundary water sharing. J Water Resour Plan Manag 123:344-349

Draper SE (ed) (2002) Model water sharing agreements for the twenty-first century. ASCE Publications, Reston

Draper SE (2004) Sharing water through interbasin transfer and basin of origin protection in Georgia: issues for evaluation in comprehensive state water planning for Georgia's surface water rivers and groundwater aquifers. Ga State Univ Law Rev 21:339

Draper SE (ed) (2006) Sharing water in times of scarcity: guidelines and procedures in the development of effective agreements to share water across political boundaries. ASCE Publications, Reston

Draper SE (2007) Administration and institutional provisions of water sharing agreements. J Water Resour Plan Manag 133:446-455

Draper SE (2012a) Effective use of shared water resources. In: World environmental and water resources congress 2012: crossing boundaries. ASCE Publications, USA, pp 2294-2305. https:// doi.org/10.1061/9780784412312.231

Draper SE (2012b) Transboundary water sharing: confronting the challenge of growing water scarcity. In: Grayman WM, Loucks DP, Saito L (eds) Toward a sustainable water future: visions for 2050. ASCE Publications, Reston, pp 46-55

Eheart JW (ed) (2002) Riparian water regulations: Guidelines for withdrawal limitations and permit trading. ASCE Publications, Reston

Fischhendler I (2004) Legal and institutional adaptation to climate uncertainty: a study of international rivers. Water Policy 6:281-302

Frey FW (1993) The political context of conflict and cooperation over international river basins. Water Int 18:54-68

Gerlak AK, Lautze J, Giordano M (2011) Water resources data and information exchange in transboundary water treaties international environmental agreements: politics. Law Econ 11:179-199

Gleditsch NP, Furlong K, Hegre H, Lacina B, Owen T (2006) Conflicts over shared rivers: resource scarcity or fuzzy boundaries? Polit Geogr 25:361-382. https://doi.org/10.1016/j.polgeo.2006.02.004

Gleick PH (2003) Global freshwater resources: soft-path solutions for the 21st century. Science 302:1524-1528

Grant DL (2003) Interstate water allocation compacts: when the virtue of permanence becomes the vice of inflexibility. Univ Colo Law Rev 74:105

Grey D, Sadoff CW (2006) Water for growth and development: thematic documents of the iv world water forum. Comision Nacional del Agua, Mexico City

Grey D, Sadoff CW (2007) Sink or swim? Water security for growth and development. Water Policy 9:545

Hamner JH, Wolf AT (1998) Patterns in international water resource treaties: the transboundary freshwater dispute database. Colo J Int Environ Law Policy 9:157-219

Jacobs JW (2002) The Mekong River Commission: transboundary water resources planning and regional security. Geogr J 168:354-364

Jones SL (2012) Digital Faces on the Cloud. In: Pontes E, Silva A, Guelfi A, Kofuji ST (eds) E-learning-organizational infrastructure and tools for specific areas. InTech, Rijeka, pp 45-62

Kallioras A, Pliakas F, Diamantis I (2006) The legislative framework and policy for the water resources management of transboundary rivers in Europe: the case of Nestos/Mesta River, between Greece and Bulgaria. Environ Sci Policy 9:291-301

Kistin EJ, Ashton PJ (2008) Adapting to change in transboundary rivers: an analysis of treaty flexibility on the Orange-Senqu River Basin. Water Resour Dev 24:385-400

Kucukmehmetoglu M, Şen Z, Özger M (2010) Coalition possibility of riparian countries via game theory and fuzzy logic models. Water Resour Res. https://doi.org/10.1029/2009wr008660

Lee H-M (1996) Applying fuzzy set theory to evaluate the rate of aggregative risk in software development. Fuzzy Sets Syst 79:323-336

Lee T, Floris V (2003) Universal access to water and sanitation: why the private sector must participate. Nat Resour Forum 27:279-290

Lohani AK, Goel NK, Bhatia KKS (2006) Takagi-Sugeno fuzzy inference system for modeling stage-discharge relationship. J Hydrol 331:146-160. https://doi.org/10.1016/j.jhydrol.2006.05.007

Lohani AK, Kumar R, Singh RD (2012) Hydrological time series modeling: a comparison between adaptive neuro-fuzzy, neural network and autoregressive techniques. J Hydrol 442-443:23-35. https:// doi.org/10.1016/j.jhydrol.2012.03.031

Loucks DP, van Beek E (2005) Water resources systems planning and management-facts about water. UNESCO, Paris

Lowi MR (1995) Water and power: the politics of a scarce resource in the Jordan River basin, vol 31. Cambridge University Press, New York

Lu R-S, Lo S-L (2002) Diagnosing reservoir water quality using selforganizing maps and fuzzy theory. Water Res 36:2265-2274

Lu R-S, Lo S-L, Hu J-Y (1999) Analysis of reservoir water quality using fuzzy synthetic evaluation. Stoch Env Res Risk Assess 13:327-336

Ma J, Hipel KW, De M, Cai J (2007) Transboundary water policies: assessment, comparison and enhancement. Water Resour Manage 22:1069-1087. https://doi.org/10.1007/s11269-007-9211-y

Mitra S, Pal SK, Mitra P (2002) Data mining in soft computing framework: a survey. IEEE Trans Neural Netw 13:3-14

Nicol A et al (2001) Transboundary water management as an international public good. Ministry of Foreign Affairs, Sweden, Stockholm

Özger M, Şen Z (2007) Prediction of wave parameters by using fuzzy logic approach. Ocean Eng 34:460-469

Pahl-Wostl C et al (2008) The importance of social learning and culture for sustainable water management. Ecol Econ 64:484-495

Phelps D (2007) Water and conflict: historical perspective. J Water Resour Plan Manag 133:382-385

Phillips D, Daoudy M, McCaffrey S, Öjendal J, Turton A (2006) Transboundary water co-operation as a tool for conflict prevention and broader benefit sharing. Ministry of Foreign Affairs Sweden, Stockholm

Qaddumi H (2008) Practical approaches to transboundary water benefit sharing. Overseas Dev Inst, London

Rahaman MM, Varis O (2005) Integrated water resources management: evolution, prospects and future challenges sustainability: science. Pract Policy 1:15-21

Rai SP, Sharma N (2016) Benefit sharing approach for the transboundary Brahmaputra River basin in south Asia: a case study. Water Energy Int 58:56-61

Rai SP, Sharma N, Lohani A (2014) Risk assessment for transboundary rivers using fuzzy synthetic evaluation technique. J Hydrol 519:1551-1559

Rai SP, Sharma N, Lohani A (2016) Transboundary water sharing: issues involved. Environ Policy Law 46:62

Rai SP, Wolf AT, Sharma N (2017a) Hydropolitics and hydropolitical dynamics between India and Nepal: an event-based study. Water Policy 19(5):791-819

Rai SP, Wolf AT, Sharma N, Tiwari H (2017b) Hydropolitics in transboundary water conflict and cooperation. In: Sharma N (ed) 
River system analysis and management. Springer, Singapore, pp 353-368

Rai SP, Young W, Sharma N (2017c) Risk and opportunity assessment for water cooperation in transboundary river basins in South Asia. Water Resour Manag 31:2187-2205

Reuss M (2002) Historical explanation and water issues. UNESCOGreen Cross International, Virginia

Rezankova H, Husek D (2012) Department of Statistics and Probability-University of Economics, Prague, Czech Republic. In: 2012 Fourth international conference on computational aspects of social networks (CASoN). IEEE, pp 277-282

Richter BD (2010) Re-thinking environmental flows: from allocations and reserves to sustainability boundaries. River Res Appl 26:1052-1063

Sadiq R, Kleiner Y, Rajani B (2004) Aggregative risk analysis for water quality failure in distribution networks. J Water Supply Res Technol AQUA 53:241-261

Sadoff CW, Grey D (2002) Beyond the river: the benefits of cooperation on international rivers. Water Policy 4:389-403

Sadoff CW, Grey D (2005) Cooperation on international rivers: a continuum for securing and sharing benefits. Water Int 30:420-427

Saffiotti A (1997) The uses of fuzzy logic in autonomous robot navigation. Soft Comput 1:180-197

Sanchez R (1997) Water conflicts between Mexico and the United States: towards a transboundary regional water market? In: Brans E, De Haan EJ (eds) The scarcity of water: emerging legal and policy responses. Kluwer Law International, London

Şen Z (2004) Fuzzy logic and system models in water sciences. Turkish Water Foundation, Istanbul

Sen Z (2009) Fuzzy logic and hydrological modeling. CRC Press, Boca Raton

Şen Z (2013) Fuzzy logic approach for international peace and sustainable development: Euphrates-Tigris river basin case. Int J Ind Syst Eng 15:238-252

Shankar T, Shanmugavel S, Karthikeyan A, Gupte AM, Sarkar S (2013) Load balancing and optimization of network lifetime by use of double cluster head clustering algorithm and its comparison with various extended LEACH versions. Int Rev Comput Softw 8:795-803

Shmueli DF (1999) Water quality in international river basins. Polit Geogr 18:437-476

Sigman H (2001) International spillovers and water quality in rivers: do countries free ride?. Natl Bur Econ Res, Cambridge

Simonovic SP (2012) Managing water resources: methods and tools for a systems approach. Routledge, Abingdon

Sneddon C, Fox C (2006) Rethinking transboundary waters: a critical hydropolitics of the Mekong basin. Polit Geogr 25:181-202. https ://doi.org/10.1016/j.polgeo.2005.11.002

TFDD (2012) International River Basin register. College of Earth, Ocean, and Atmospheric Sciences, Oregon State University, Corvallis

Tiwari H, Sharma N (2014) River science research: multidisciplinary to trans disciplinary. J Water Resour Eng Manag 1:15-19

Toset HPW, Gleditsch NP, Hegre H (2000) Shared rivers and interstate conflict. Polit Geogr 19:971-996
Turton A (2008) A South African perspective on a possible benefitsharing approach for transboundary waters in the SADC region. Water Altern 1:180-200

van Binsbergen WMJ (2003) Cultures do not exist': exploding selfevidences in the investigation of interculturality. Leiden University Repository, Leiden

Warner J (2004) Mind the GAP-working with Buzan: the Illisu Dam as a security Issue. SOAS Water Issues Study Group, School of Oriental and African Studies/King's College London, University of London, London, UK

Warner JF, Zeitoun M (2008) International relations theory and water do mix: a response to Furlong's troubled waters, hydro-hegemony and international water relations. Polit Geogr 27:802-810. https ://doi.org/10.1016/j.polgeo.2008.08.006

Waterbury J (2002) The Nile basin: national determinants of collective action. Yale University Press, New Haven

Winpenny J, Camdessus M (2003) Financing water for all. Global Water Partnership, World Water Council, World Water Forum, Kyoto

Wolf AT (1997) International water conflict resolution: lessons from comparative analysis. Int J Water Resour Dev 13:333-366

Wolf AT (1998) Conflict and cooperation along international waterways. Water Policy 1:251-265

Wolf AT (1999a) Criteria for equitable allocations: the heart of international water conflict. Nat Resour Forum 23:3-30

Wolf AT (1999b) The transboundary freshwater dispute database project. Water Int 24:160-163

Wolf AT (1999c) "Water wars" and water reality: conflict and cooperation along international waterways.In: Lonergan SC (ed) Environmental change, adaptation, and security. NATO ASI Series (2. Environment), vol 65. Springer, Dordrecht, pp 251-265

Wolf AT (2001) Transboundary waters: sharing benefits, lessons learned. In: International conference on freshwater (Hrsg.): thematic background papers. International Conference on Freshwater, Bonn

Wolf AT (2002) Conflict prevention and resolution in water systems. In: Howe CW (ed) The management of water resources series. Edward Elgar Publishing Ltd, Cheltenham

Zadeh LA (1968) Fuzzy algorithms. Inf Control 12:94-102

Zeitoun M, Warner J (2006) Hydro-hegemony - a framework for analysis of trans-boundary water conflicts. Water Policy 8:435-460. https://doi.org/10.2166/wp.2006.054

Zeitoun M, Mirumachi N, Warner J (2010) Transboundary water interaction II: the influence of 'soft' power international environmental agreements: politics. Law Econ 11:159-178. https://doi. org/10.1007/s10784-010-9134-6

Publisher's Note Springer Nature remains neutral with regard to jurisdictional claims in published maps and institutional affiliations. 